\title{
Successful medical treatment of fetal supraventricular tachycardia that cause hydrops fetalis
}

\section{Hidrops fetalise neden olan fetal supraventriküler taşikardinin başarilı medikal tedavisi}

\author{
Cihan Çetin1 ${ }^{1}$, Çiğdem Akçabay², Selim Büyükkurt ${ }^{1}$, Nazan Özbarlas 3 \\ ${ }^{1}$ Çukurova University Faculty of Medicine, Department of Obstetrics and Gynecology, Adana, Turkey \\ ${ }^{2}$ Elazı ̆ Research and Education Hospital, Clinic of Obstetrics and Gynecology, Elazığ, Turkey \\ ${ }^{3}$ Çukurova University Faculty of Medicine, Department of Pediatric Cardiology, Adana, Turkey
}

\begin{abstract}
Supraventricular tachycardia (SVT) is the most frequent fetal tachyarrhythmia. Diagnosis is established with M-mode ultrasound and/or Doppler investigation. Untreated cases may develop fetal heart failure and hydrops. Even these cases should not be left untreated - maternal administration of antiarrhythmic drugs should be undertaken. In this manuscript, we describe a successful treatment with maternal administration of sotalol and digoxin in a fetus that developed hydrops because of SVT. J Turk Soc Obstet Gynecol 2014;3:193-5
\end{abstract}

Key Words: Tachycardia, supraventricular, fetal hydrops

Özet

Supraventriküler taşikardi (SVT) en sık gözlenen fetal taşiaritmidir. Tanısı M-Mod ultrason ve/veya Doppler incelemeleri ile konur. Tedavisiz bırakılan olgularda fetal kalp yetmezliği ve hidrops gelişebilir. Bu tür komplikasyonların geliştiği olgularda tedavisiz bırakılmamalı, anneye verilen antiaritmik ilaçlarla tedavi edilmeye çalışılmalıdır. Yazımızda fetal SVT nedeniyle hidrops gelişmiş bir fetusun maternal sotalol ve digoksin uygulaması ile başarılı tedavisini anlatacağız. J Turk Soc Obstet Gynecol 2014;3:193-5

Anahtar Kelimeler: Taşikardi, supraventriküler, fetal hidrops

\section{Introduction}

Supraventricular tachycardia (SVT) is the most frequent fetal tachyarrhythmia(1). There was difficulty in the prenatal diagnosis of fetal arrhythmias before the advances in the ultrasound technology. Currently, they can be identified in detail. Especially, M-mode echocardiography is very helpful in the identification of fetal arrhythmias. SVT, if untreated or overlooked by the inadequate evaluation, may cause ventricular dysfunction and hydops fetalis. The most important factor in progression to hydrops fetalis is the heart rate and duration and progression rate of SVT(2). Untreated cases of hydrops may easily cause death of fetus or hypoxic events caused by the impaired systemic perfusion in the fetus. In the cases of fetal SVT's, there are various management strategies at different clinics depending on their own experiences. These include expectant management, birth and postnatal treatment, fetal intramuscular injections and maternal administration of drugs $(3)$. Drugs used in the prenatal period include digoxin, sotalol, flecainide and amiodarone(4). In this manuscript, we present the treatment of a hydropic fetus by the maternal administration of digoxin and sotalol.

\section{Case}

Patient was referred to our prenatal diagnosis center during her 24 weeks of gestation due to fetal ascites. Upon evaluation, the patient did not have any prior significant medical or surgical history. Ultrasonographic evaluation revealed fetal ascites with fetal supraventricular tachycardia. No additional finding that may cause ascites was found during ultrasound examination. Fetal heart rate was 273 beats/min and every atrial contraction was followed by a ventricular contraction. Patient was given digoxin (bolus: $500 \mu \mathrm{g} 2 \mathrm{xl}$ PO, maintenance: $250 \mu \mathrm{g}$ 2xl PO) and sotalol (160 mg 2x1 PO) for four days. Patient was followed by electrocardiography (ECG) (especially corrected QT interval) and blood digoxin levels. Due to persistant fetal tachycardia, 
sotalol dose was elevated to $320 \mathrm{mg} 3 \mathrm{xl}$ in the following four days. On the eigth day of treatment fetaus was on sinus rhythm and heart rate was 140 beats/min. During the follow-up period, no tachycardia episodes were identified and on account of this sotalol dose gradually decreased to $80 \mathrm{mg} 2 \times 1$ on the $13^{\text {th }}$ day of treatment. Fetal ascites completely resolved on the $11^{\text {th }}$ day of treatment (Figure 1). On the third week of treatment sotalol dose remained same, whereas digoxin dose was decreased to $250 \mu \mathrm{g} 1 \mathrm{x} 1$. During the rest of the pregnancy no episodes of fetal tachycardia and ascites was observed at ultrasonographic evaluations. Patient delivered a male fetus vaginally on the 38 weeks of gestation and infant had no complication (cardiac, neurologic etc.) during the postnatal six months period.

\section{Discussion}

Hydrops fetalis is usually divided into two categories: İmmune and non-immune hydrops fetalis. The most important etiologic factor for immune hydrops fetalis is $\mathrm{Rh}$ isoimmunization and this is markedly decreased in the past three-four decades by the effective administration of prophylactic regimens; currently most of the hydops fetalis cases were in the category of nonimmune group and the etiology of these are multifactorial(5). Despite the advances in the etiopatogenesis and treatment of hydrops fetalis, mortality rate still remains near $50 \%(5,6)$. As it can be thought, survival without neurologic sequela is even less. Especially, M-mode should be chosen during the evaluation of arrhythmias with the ultrasound. M-mode line should be placed passing from both atrium and ventricle so that evaluation of the relation between atrial and ventricular contractions can be made. Another option is the placement of the line passing from both atrium and aorta. By this way, atrial rate, ventricular rate, relation between atrial and ventricular beats and the type of the arrhythmia can be determined.

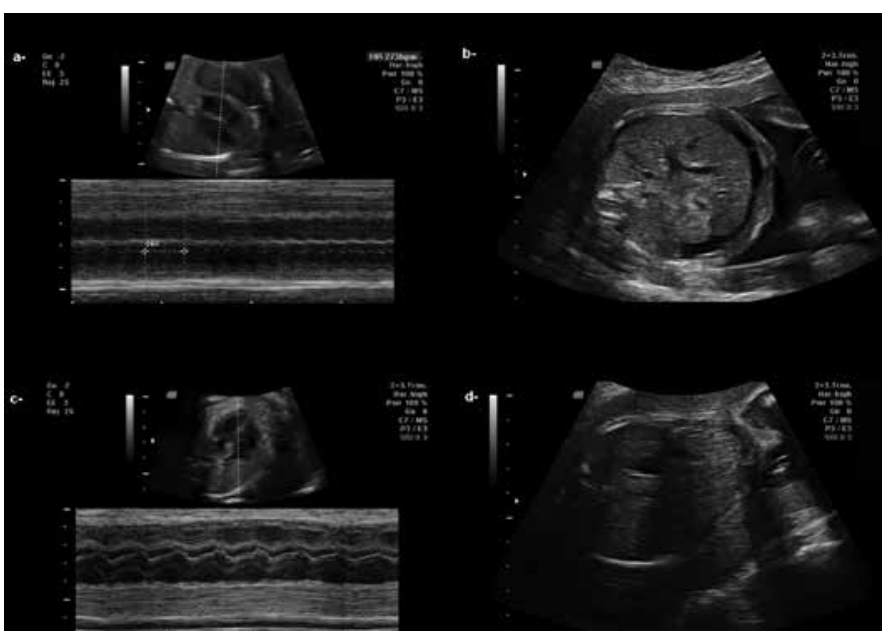

Figure 1. Before the treatment, M-mode shows tachycardia in which every atrial contraction follows a ventricular contraction (a) and the presence of ascites (b). At the $11^{\text {th }}$ day of treatment, heart rate returned to sinus rhythm (c) and ascites completely resolved $(d)$
Sotalol is a beta adrenergic reseptor blocker class III 3 antiarrhythmic drug that prolongs the cardiac repolarization interval(7). Like other antiarrhythmic drugs, sotalol has also proarrhythmic potential. It is especially chosen in the treatment of fetal arrhythmias due to its fast and adequate crossing from the placenta(7). Digoxin exhibits its effect by both increasing the refractoriness at the atrioventricular node and having positive inotrophic effect. Digoxin should not be used alone in the treatment of fetal SVT due to the potential existence of an atrioventricular accessory pathway $(8)$. It is usually used together with drugs like sotalol or flecainide. Digoxin is also thought to be effective in the hydropic cases due to its positive inotrophic effect ${ }^{(8)}$.

One of the other drugs used in the antiarrhythmic treatments, flecainide needs serum level follow-up and another drug, amiodarone has potential risk of developing fetal hypothyroidism; on account of these, sotalol is thought to be safer in the first-line treatment ${ }^{(9-12)}$. Only ECG follow-up at certain periods is enough for the patients given sotalol(13).

The recommended bolus dose is between 250-1500 $\mu \mathrm{g}$ and maintanence dose is between 125-500 $\mathrm{\mu g}$ for digoxin(3). Although the recommended dose for sotalol is $160 \mathrm{mg}$ PO two times a day, it can be increased to maximum dose of $160 \mathrm{mg}$ $\mathrm{PO}$ three times a day. Whereas we achieved to treat SVT in our patient by $320 \mathrm{mg}$ three times a day. However, we did not encounter any maternal side effect.

The major concern with the use of maternally administered drugs is their proarrythmic effect (especially long QT on ECG). QT interval may be effected by the heart rate, on). Multiple studies in the literature suggest not to avoid the use of these drugs especially in the pregnant patients, because of their very low potential for such an adverse effect $(9,13)$. After the resolution of fetal tachycardia, the patient should be followed with the minimum maintenance dose. Another tool in the following of digoxin theraphy is the blood level of the drug. When blood digoxin levels exceeds $1.3-1.5 \mathrm{ng} / \mathrm{mL}$, signs of toxicity may appear. In order to determine the correct blood level of digoxin, blood sample should be taken at least six hours after the intake of last dose. By the resolution of tachycardia, fetal monitoring during the labor becomes easier and unnecessary ceserean rates would decrease, also.

Moodle et al. defined hydrops fetalis, female fetus and unsuccessful resolution of the arrythmia as potential risk factors for postnatal arrythmia(14). As compatible with this, male fetus and successful return to sinus rhythm prenatally was thought good prognostic factors in our case; however, despite the existence of poor prognostic factor hydrops fetalis, no postnatal arrythmia was observed.

In conclusion, the aim should be to treat fetal tachycardia before the development of hydrops. However, even for the cases in which hydrops already developed, treatment should not be avoided, and optimal drug dose for mother and the fetus should be given. The following of medical treatment should be done 
by both maternal and fetal parameters. Although no standart dosing of the drugs has been established yet, our case is one of the few cases describing the treatment experience in this condition in our country.

\section{References}

1. Husain A, Hubail Z, Al Banna R. Fetal supraventricular tachycardia, treating the baby by targeting the mother. BMJ Case Rep 2013.

2. Suri V, Keepanaseril A, Aggarwal N, Vijayvergiya R. Prenatal management with digoxin and sotalol combination for fetal supraventricular tachycardia: case report and review of literature. Indian J Med Sci 2009;63:411-4.

3. Oudijk MA, Ruskamp JM, Ambachtsheer BE, Ververs TF, Stoutenbeek P, Visser GH, et al. Drug treatment of fetal tachycardias. Paediatr Drugs 2002;4:49-63.

4. Maeno Y, Hirose A, Kanbe T, Hori D. Fetal arrhythmia: prenatal diagnosis and perinatal management. J Obstet Gynaecol Res 2009;35:623-9.

5. Fukushima K, Morokuma S, Fujita Y, Tsukimori K, Satoh S, Ochiai $\mathrm{M}$ et al. Short-term and long-term outcomes of 214 cases of nonimmune hydrops fetalis. Early Hum Dev 2011;87:571-5.

6. Takci S, Gharibzadeh M, Yurdakok M, Ozyuncu O, Korkmaz A, Akcoren Z, et al. Etiology and outcome of hydrops fetalis: Report of 62 cases. Pediatr Neonatol 2014;55:108-13.
7. van der Heijden LB, Oudijk MA, Manten GT, ter Heide H, Pistorius L, Freund MW. Sotalol as first-line treatment for fetal tachycardia and neonatal follow-up. Ultrasound Obstet Gynecol 2013;42:285-93.

8. Uzun O, Babaoglu K, Sinha A, Massias S, Beattie B. Rapid control of foetal supraventricular tachycardia with digoxin and flecainide combination treatment. Cardiol Young 2012;22:372-80.

9. Oudijk MA, Ruskamp JM, Ververs FF, Ambachtsheer EB, Stoutenbeek P, Visser GH, et al. Treatment of fetal tachycardia with sotalol: transplacental pharmacokinetics and pharmacodynamics. J Am Coll Cardiol 2003;42:765-70.

10. Pézard PG, Boussion F, Sentilhes L, Lépinard C, Couvreur MH, Victor J, et al. Fetal tachycardia: a role for amiodarone as first- or secondline therapy? Arch Cardiovasc Dis 2008;101:619-27.

11. Khositseth A, Ramin KD, O'Leary PW, Porter CJ. Role of amiodarone in the treatment of fetal supraventricular tachyarrhythmias and hydrops fetalis. Pediatr Cardiol 2003;24:454-6.

12. Jouannic JM, Delahaye S, Fermont L, Le Bidois J, Villain E, Dumez Y, et al. Fetal supraventricular tachycardia: a role for amiodarone as second-line therapy? Prenat Diagn 2003;23:152-6.

13. Shah A, Moon-Grady A, Bhogal N, Collins KK, Tacy T, Brook M, et al. Effectiveness of sotalol as first-line therapy for fetal supraventricular tachyarrhythmias. Am J Cardiol 2012;109:1614-8.

14. Moodley S, Sanatani S, Potts JE, Sandor GG. Postnatal outcome in patients with fetal tachycardia. Pediatr Cardiol 2013;34:81-7. 